\section{[o]Ka \\ JURNAL INOVASI \& KREATIFITAS}

JURNAL INOVASI DAN KREATIFITAS (JIKa)

Volume 1 Nomor 2 September 2021; p-ISSN 2776-1843, e-ISSN 2807-8047

DOI: $10.30656 / j i k a . v 1 \mathrm{i} 2.3820$

https://e-jurnal.Ippmunsera.org/index.php/JIKa

SK No. 0005.27761843/K.4/SK.ISSN/2021

\title{
PENGARUH MODEL PEMBELAJARAN THINK PAIR SHARE (TPS) TERHADAP HASIL BELAJAR EKONOMI PADA SISWA KELAS X DI SMA KUTABUMI I TANGERANG, BANTEN
}

\section{THE EFFECT OF THINK PAIR SHARE (TPS) LEARNING MODEL ON ECONOMIC LEARNING OUTCOMES IN CLASS X STUDENTS AT SMA KUTABUMI I TANGERANG, BANTEN}

\author{
Khoirudin $^{\mathrm{a}}$, Supriyanah ${ }^{\mathrm{a}}$ \\ ${ }^{a}$ Dosen Pendidikan Guru Anak Usia Dini Fakultas Keguruan Dan Ilmu Pendidikan, \\ Universitas Nahdlatul Ulama Indonesia. \\ a Mahasiswa Pendidikan Guru Anak Usia Dini Fakultas Keguruan Dan Ilmu Pendidikan, \\ Universitas Nahdlatul Ulama Indonesia. \\ 1khoirudin@unusia.ac.id, 2supriyanah@gmail.com
}

\begin{abstract}
Problem: From observations and preliminary research conducted, information is obtained that the daily test for the field of Economics study is still below the KKM, in this case SMA Kutabumi I Tangerang, West Java set the KKM for the field of Economics study is 70. However, the average student learning outcomes $X$ for the first daily test reaches a value of 60.22 so $40 \%$ of students must take remedial.
\end{abstract}

Purpose: To determine the effect of the Think Pair Share Model on Economics Learning Outcomes in Class X Students at SMA Kotabumi Tangerang, Banten.

Methodology: Methodology This research uses quantitative methods which are carried out through the experimental method, namely by giving different treatments to the control class and the experimental class, then from the treatment, the learning outcomes that may be achieved by the two groups will be compared. 
Results/Findings: learning through Think Pair Share model has an average learning outcome of 85.26, while the lowest score is 73.00 and the highest score is 97.00. This value is higher than the achievement of student learning outcomes who are given learning through Problem Based Instruction (PBI) where the average value of learning outcomes is 63.68 and the lowest score is 57.00 and the highest score is 73.00 .

Paper type : Eksperiment.

Keywords: Think Pair Share Model, Economic Learning Outcomes,

Abstrak

Masalah : Dari pengamatan dan penelitian awal yang dilakukan diperoleh informasi bahwa ulangan harian untuk bidang study Ekonomi, selam ini masih berada dibawah KKM, dalam hal ini SMA Kutabumi I Tangerang, Jawa Barat menetapkan KKM untuk bidang study Ekonomi adalah 70. Namun rata-rata hasil belajar siswa X untuk ulangan harian pertama mencapai nilai 60,22 sehinga $40 \%$ peserta didik harus mengikuti remedial.

Tujuan : Mengetahui Pengaruh Model Pembelajaran Think Pair Share Terhadap Hasil Belajar Ekonomi Pada Siswa kelas X di SMA kotabumi Tangerang, Banten.

Metodologi : Metodologi Penelitian ini menggunakan metode kuantitatif yang dilakukan melalui metode eksperimen yaitu dengan memberikan perlakuan yang berbeda kepada kelas kontrol dan kelas eksperimen, selanjutnya dari perlakuan tersebut akan dibandingkan hasil belajar yang mungkin diraih oleh kedua kelompok tersebut.

Temuan/Hasil Penelitian : pembelajaran melalui Think Pair Share memiliki rata-rata hasil belajar 85,26, sedangkan nilai terendah adalah 73,00 dan nilai tertinggi 97,00. Nilai tersebut lebih tinggi dari pencapaian hasil belajar siswa yang diberi pembelajaran melalui Problem Based Instruction (PBI) dimana nilai rata-rata hasil belajar adalah 63,68 dan nilai terendah 57,00 serta nilai tertinggi 73,00.

Jenis Penelitian : Eksperimen

Kata Kunci : Model Pembelajaran Think Pair Share, Hasil Belajar Ekonomi, 


\section{A. PENDAHULUAN}

Bagi kita yang aktif dalam dunia pendidikan ataupun yang memiliki high responsibility tinggi terhadap dunia pendidikan pasti akan selalu memepertanyakan beberapa hal yang terkait langsung dengan dunia pendidikan, yaitu apa itu belajar, mengajar dan pembelajaran? Secara sederhana.(Omeri, 2015) Anthony Robbins, mendefinisikan belajar sebagai proses menciptakan hubungan antara sesuatu (pengetahuan) yang sudah di pahami dan sesuatu (pengetahuan) yang baru.(Syafitri, 2014) Pandangan Anthony Robbins senada dengan apa yang di kemukakan oleh Jerome Brunner dalam (Romberg \& Kaput, 1999), bahwa belajar adalah suatu proses aktif dimana siswa membangun (mengkonstruk) pengetahuan baru berdasarkan pada pengalaman/ pengetahuan yang sudah dimilikinya. Dalam pandangan konstruktivisme 'belajar' bukanlah semata-mata mentransfer pengetahuan yang ada di luar darinya, tetapi belajar lebih pada bagaimana otak memproses dan menginterpretasikan pengalaman yang baru dengan pengetahuan yang sudah dimilikinya dalam format yang baru.

\section{B. KERANGKA TEORI}

\section{Pengertian Model Pembelajaran Think, Pair and Share}

Pengertian Think Pair Share (TPS) atau berpikir berpasangan berbagi merupakan jenis pembelajaran kooperatif yang di reancang untuk mempengaruhi pola interaksi siswa. Strategi TPS ini berkembang dari penelitian kooperatif dan waktu tunggu. Pertama kali dikembangkan oleh Frang Lyman dan koleganya di Universitas Maryland yang menyatakan bahwa TPS merupakan cara yang efektif untuk membuat variasi suasana pola diskusi kelas (Astuti, 2017).

Model Pembelajaran TPS (Think, Pair dan Share) - Strategi Think Pair Share (TPS) atau berfikir berpasangan berbagi merupakan jenis pembelajaran kooperatif yang dirancang untuk mempengaruhi pola interaksi siswa. Strategi Think Pair Share (TPS) ini berkembang dari penelitian belajar koopertif. Strategi Think Pair Share (TPS) pertama kali dikembangkan oleh Frank Lyman dan koleganya di Universitas Marryland.k(Kusuma \& Aisyah, 2012).

Think Pair Share merupakan suatu cara yang efektif untuk membentuk variasi suasana diskusi kelas. Model pembelajaran Think Pair Share merupakan salah satu model pembelajaran yang jarang di terapkan oleh guru di dalam kelas (Surayya et al., 2014).

Arends menyatakan bahwa Think Pair Share (TPS) merupakan suatu cara yang efektif untuk membuat variasi suasana pola diskusi kelas. Dengan asumsi bahwa semua diskusi membutuhkan pengaturan untuk mengendalikan kelas secara keseluruhan dan proses yang digunakan dalam Think Pair Share (TPS) dapat memberi siswa waktu yang lebih banyak untuk berfikir, untuk merespon dan saling membantu(Winantara \& Jayanta, 2017). Dikemukakan oleh Lie, "Think Pair Share adalah pembelajaran yang memberi siswa kesempatan untuk bekerja sendiri dan bekerjasama dengan orang lain"

Sedangkan menurut Gunter ThinkPair-Share adalah pembelajaran dengan cara siswa saling belajar satu sama lain dan mendapatkan jalan keluar dari ide mereka setelah berdiskusi dan membuat ide mereka untuk didiskusikan dalam seluruh kelas (Mutatik, 2018)

Hal senada juga disampaikan oleh Ibrahim, dkk, mereka menyatakan bahwa TPS (Think-Pair-Share) atau (BerfikirBerpasangan-Berbagi) merupakan jenis pembelajaran kooperatif yang dirancang untuk mempengaruhi pola interaksi siswa (Suleman, 2018), Think-Pair-Share menghendaki siswa bekerja saling 
membantu dalam kelompok kecil (2-6 anggota) dan lebih dirincikan oleh penghargaan kooperatif, dari pada penghargaan individual.

Model pembelajaran Think Pair Share merupakan salah satu model pembelajaran kooperatif sederhana. Dengan model pembelajaran ini siswa dilatih bagaimana mengutarakan pendapat dan siswa juga belajar menghargai pendapat orang lain dengan tetap mengacu pada materi/tujuan pembelajaran. Think Pair Share dirancang untuk mempengaruhi interaksi siswa. Struktur ini menghendaki siswa bekerja saling membantu dalam kelompokkelompok kecil (Tanzimah, 2020).

Think Pair Share dapat meningkatkan kemampuan siswa dalam mengingat suatu informasi dan seorang siswa juga dapat belajar dari siswa lain serta saling menyampaikan idenya untuk didiskusikan sebelum disampaikan di depan kelas. Selain itu, Think Pair Share juga dapat memperbaiki rasa percaya diri dan semua siswa diberi kesempatan berpartisipasi dalam kelas.

Ciri utama pada model pembelajaran kooperatif tipe Think-Pair-Share adalah tiga langkah utamanya yang dilaksanakan dalam proses pembelajaran. Yaitu langkah think (berpikir secara individual), pair (berpasangan dengan teman sebangku), dan share (berbagi jawaban dengan pasangan lain atau seluruh kelas).

\section{a. Think (berpikir secara individual)}

Pada tahap think, guru mengajukan suatu pertanyaan atau masalah yang dikaitkan dengan pelajaran, dan siswa diminta untuk berpikir secara mandiri mengenai pertanyaan atau masalah yang diajukan. Pada tahapan ini, siswa sebaiknya menuliskan jawaban mereka, hal ini karena guru tidak dapat memantau semua jawaban siswa sehingga melalui catatan tersebut guru dapat mengetahui jawaban yang harus diperbaiki atau diluruskan di akhir pembelajaran. Dalam menentukan batasan waktu untuk tahap ini, guru harus mempertimbangkan pengetahuan dasar siswa untuk menjawab pertanyaan yang diberikan, jenis dan bentuk pertanyaan yang diberikan, serta jadwal pembelajaran untuk setiap kali pertemuan.

Kelebihan dari tahap ini adalah adanya "think time" atau waktu berpikir yang memberikan kesempatan kepada siswa untuk berpikir mengenai jawaban mereka sendiri sebelum pertanyaan tersebut dijawab oleh siswa lain. Selain itu, guru dapat mengurangi masalah dari adanya siswa yang mengobrol, karena tiap siswa memiliki tugas untuk dikerjakan sendiri.

\section{b. Pair (berpasangan dengan teman sebangku)}

Langkah kedua adalah guru meminta para siswa untuk berpasangan dan mendiskusikan mengenai apa yang telah dipikirkan. Interaksi selama periode ini dapat menghasilkan jawaban bersama. Biasanya guru mengizinkan tidak lebih dari 4 atau 5 menit untuk berpasangan. Setiap pasangan siswa saling berdiskusi mengenai hasil jawaban mereka sebelumnya sehingga hasil akhir yang didapat menjadi lebih baik, karena siswa mendapat tambahan informasi dan pemecahan masalah yang lain.

\section{c. Share (berbagi jawaban dengan pasangan lain atau seluruh kelas)}

Pada langkah akhir ini guru meminta pasangan-pasangan tersebut untuk berbagi hasil pemikiran mereka dengan pasangan lain atau dengan seluruh kelas. Pada langkah ini akan menjadi efektif jika guru berkeliling kelas dari pasangan satu ke pasangan yang lain, sehingga seperempat atau separuh dari pasangan-pasangan tersebut memperoleh kesempatan untuk melapor. Langkah ini merupakan penyempurnaan dari langkah-langkah sebelumnya, dalam arti bahwa langkah ini menolong agar semua kelompok menjadi lebih memahami mengenai pemecahan 
masalah yang diberikan berdasarkan penjelasan kelompok yang lain. Hal ini juga agar siswa benar-benar mengerti ketika guru memberikan koreksi maupun penguatan di akhir pembelajaran

\section{METODOLOGI PENELITIAN}

Penelitian dengan menggunakan metode kuantitatif yang dilakukan melalui metode eksperimen yaitu dengan memberikan perlakuan yang berbeda kepada kelas kontrol dan kelas eksperimen, selanjutnya dari perlakuan tersebut akan dibandingkan hasil belajar yang mungkin diraih oleh kedua kelompok tersebut.

Dalam penelitian eksperimen perlu adanya control langsung pada variabel bebas. Disain dasar penelitian ini adalah disain eksperimen dan dipilih serta disesuaikan dengan hipotesis penelitian. Pelaksanaan eksperimen disusun berdasarkan model Solomon, hal ini dipilih dengan asumsi bahwa kelompok eksperimen dan kelompok kontrol diperoleh berdasarkan pengundian yang ekuivalen.(Payadnya \& Jayantika, 2018)

\section{Rancangan Perlakuan}

a. Definisi Konseptual

Ilmu ekonomi adalah suatu budang studi bagaimana orang-orang dan masyarakat membuat pilihan dengan atau tanpa penggunaan uang dengan menggunakan sumber-sumber daya yang terbatas tetapi dapat dipergunakan dalam berbagai cara untuk menghasilkan berbagai jenis barang dan jasa dan mendistribusikannya untuk keperluan sekarang dan di masa akan datang kepada berbagai orang dan golongan masyarakat (Trisnantoro, 2018) .

b. Definisi Operasional

Ilmu pengetahuan yang mempelajari tentang bagaimana manusia memenuhi kebutuhan hidupnya yang bersifat tidak terbatas dengan jumlah alat pemuas kebutuhan yang bersifat terbatas, maka instrument tes hasil belajar disusun melalui beberapa dimensi diantaranya:

1. Teori Ekonomi Mikro

2. Teori Ekonomi Makro

3. Ekonomi Terapan

\section{Kontrol Validitas Internal dan} Eksternal Rancangan Penelitian

Kelayakan instrument penelitian dapat diungkapkan melalui perhitungan validitas, yaitu nilai yang menyatakan kemampuan atau kesahihan alat ukur yang digunakan dalam penelitian. Berdasarkan skor yang diperoleh untuk tes hasil belajar siswa kelas $\mathrm{X}$ SMA Kutabumi I Tangerang, Jawa Barat. Dimana jawaban berada dalam interval 0 (untuk jawaban yang salah) dan 1 (untuk jawaban yang benar).

\section{Teknik Pengumpulan Data}

Pada penelitian ini memiliki dua instrumen variabel yang akan di uji yaitu:

\section{a. Instrumen Variabel $\quad Y \quad$ (Hasil Belajar)}

1) Definisi Konseptual

Hasil belajar pada hakikatnya adalah serangkaian kemampuan yang dimiliki siswa setelah kegiatan belajar berlangsung. Pembelajaran dikatakan berlangsung optimal jika siswa mampu mencapai perubahan yang maksimal dari peoses pembelajaran yang dilaluinya. Hasil belajar adalah beragam kemampuan yang dimiliki siswa setelah iya menerima pengalam belajar. Pernyataan ini mempertegas bahwa hasil belajar dipengaruhi oleh proses belajar yang dilaluinya. Hasil belajar tidak hanya terbatas pada kemampuan menghafal atau 
mengingat, namun hasil belajar juga mencakup sikap, etika, prilaku, kemapuan bertindak dan berbagai kemapuan lain yang bermanfaat bagi siswa.

Hasil belajar merupakan tingkat perkembangan mental yang lebih baik bila dibandingkan sebelum belajar dan setelah belajar. Hasil belajar, merupakan saat terselesaikannya bahan pelajaran. Menurut devinisi tersebut hasil belajar dapat diukur sesuai dengan kebutuhan yang diinginkan, bila didasarkan atas proses pendidikan maka hasil belajar adalah peningkatan kualitas mental siswa setelah mengikuti proses belajar

Kisi-Kisi Hasil Belajar

\begin{tabular}{|c|c|c|}
\hline No & Dimensi & Indikator \\
\hline 1 & Pengamatan & $\begin{array}{l}\text { 1. Dapat Mendeskripsikan } \\
\text { pengertian ilmu ekonomi } \\
\text { 2. Dapat Mendeskripsikan } \\
\text { pembagian ilmu ekonomi }\end{array}$ \\
\hline 2 & Ingatan & $\begin{array}{l}\text { 1. Menjelaskan pengertian } \\
\text { ilmu ekonomi } \\
\text { 2. Menyebutkan kegunaan } \\
\text { mempelajari ilmu } \\
\text { ekonomi }\end{array}$ \\
\hline 3 & Pengamatan & $\begin{array}{l}\text { 1. Dapat menyajikan hasil } \\
\text { telaah tentang } \\
\text { perkembangan ilmu } \\
\text { ekonomi Indonesia } \\
\text { 2. Dapat mendefinisikan } \\
\text { dengan lisan }\end{array}$ \\
\hline
\end{tabular}

2) Jenis Instrumen

Untuk lebih mengoperasionalkan keberadaan varibel hasil belajar siswa dalam bidang studi Ekonomi untuk materi Perekonomian Indonesia, maka instrument tes hasil belajar disusun melalui beberapa dimensi diantaranya :
1. Teori Ekonomi Mikro

2. Teori Ekonomi Makro

3. Ekonomi Terapan

3) Uji Validitas dan Reliabilitas

Kelayakan instrument penelitian dapat diungkapkan melalui perhitungan validitas, yaitu nilai yang menyatakan kemampuan atau kesahihan alat ukur yang digunakan dalam penelitian. Berdasarkan skor yang diperoleh untuk tes hasil belajar siswa kelas X SMA Kutabumi I Tangerang, Jawa Barat. Dimana jawaban berada dalam interval 0 (untuk jawaban yang salah) dan 1 (untuk jawaban yang benar).

\section{b. Instrumen Variabel $\mathrm{X}$ (Model Pembelajaran)}

1. Definisi Konseptual

Model pembelajaran adalah suatu pengetahuan tentang cara-cara mengajar yang dipergunakan oleh guru atau instruktur. Pengertian lain mengatakan bahwa model pembelajaran merupakan teknik penyajian yang dikuasai oleh guru untuk mengajar atau menyajikan bahan pelajaran kepada siswa di dalam kelas, baik secara individual ataupun secara kelompok agar pelajaran itu dapat diserap, dipahami dan dimanfaatkan oleh siswa dengan baik.

\section{Definisi Operasional}

Model pembelajaran adalah suatu cara atau upaya yang dilakukan oleh para pendidik agar proses belajarmengajar pada siswa tercapai sesuai dengan tujuan. Model pembelajaran adalah cara yang dipergunakan guru dalam mengadakan hubungan dengan siswa pada saat berlangsung pembelajaran. Menempati peranan yang tak kalah penting dalam proses belajar mengajar. Dalam pemilihan 
model pembelajaran apa yang tepat, guru harus melihat situasi dan kondisi siswa serta materi yang diajarkan.

Sesuai dengan model pembelajaran penelitian yang dipergunakan maka data diperoleh dari hasil belajar siswa melalui alat test berbentuk pilihan ganda yang diberikan kepada kedua kelompok kelas penelitian yaitu kelas eksperimen atau siswa yang diperoleh pembelajaran melalui model pembelajaran Think Pair Share (TPS) dan kelas kontrol atau kelompok siswa yang tidak menggunakan model pembelajaran Think Pair Share (TPS).

\section{B. Teknik Anilisis Data}

Analisis data dilakukan melalui tiga tahapan, yaitu tahap deskripsi data, tahap uji persyaratan analisis, dan tahap pengujian hipotesis.

\section{Tahap Deskripsi Data}

Langkah-langkah yang dilakukan pada tahap deskripsi data ini adalah membuat tabulasi data untuk setiap variabel, mengurutkan data secara interval dan menyusunnya dalam bentuk tabel distribusi frekuensi, mencari modus, median, rata-rata (mean), dan simpangan baku. Deskripsi data dilakukan dengan menggunakan program komputer SPSS.

\section{Tahap Uji Persyaratan Analisis}

Uji persyaratan analisis yang akan dilakukan adalah uji normalitas dan uji homogenitas. Uji normalitas dilakukan untuk mengetahui normal tidaknya sebaran data yang akan dianalisis sedangkan uji homogenitas untuk memastikan kelompok data berasal dari populasi yang homogen. Uji normalitas menggunakan uji Lilliefors, sedangkan uji homogenitas menggunakan uji Bartleth.

\section{Tahap Pengujian Hipotesis}

Pengujian hipotesis penelitian dilakukan dengan menggunakan analisis korelasi dan regresi, di mana untuk menguji hipotesis pertama dan kedua digunakan teknikan analisis korelasi dan regresi linear sederhana sedangkan untuk menguji hipotesis ketiga digunakan teknik korelasi dan regresi linear ganda. Uji keberartian menggunakan uji $\mathrm{t}$ dan uji $\mathrm{F}$ pada taraf signifikansi $\alpha=0,05$.

\section{Hipotesis Statistik}

Hipotesis statistik merupakan jawaban sementara dari pertanyaanpertanyaan, untuk mengetahui seberapa besar pengaruh antar variabel tersebut. Maka rumus yang digunakan sebagai berikut :

$$
\begin{aligned}
& \text { H0 : } \mu 1 \leq \mu 2 \\
& \text { H1 }: \mu 1 \geq \mu 2
\end{aligned}
$$

Keterangan :

$\mu 1$ : rata-rata hasil belajar Ekonomi siswa yang diberi pembelajaran menggunakan model pembelajaran Think Pair Share (TPS).

$\mu 2$ : rata-rata belajar Ekonomi siswa yang tidak diberi model pembelajaran Think Pair Share (TPS).

\section{HASIL DAN PEMBAHASAN}

Model pembelajar memiliki peran terhadap proses belajar siswa, kondisi sedemikian akan berpengaruh langsung terhadap kegiatan yang dilakukan siswa selanjutnya akan mempengaruhi penguasaan materi serta pencapaian hasil belajar. Berdasarkan karakteristik kegiatan belajar yang dikembangkan melalui dua pendekatan belajar, secara langsung mempengaruhi pula terhadap hasil belajar. Melalui data hasil analisis diperoleh informasi bahwa nilai terendah untuk hasil belajar.

Semakin komplek dan semakin 
terencana pengelolaan proses pembelajaran akan semakin optimal pula perubahan tingkah laku yang diperoleh siswa. Kegiatan belajar merupakan usaha aktif dari siswa untuk mengubah perilaku dan kemampuan sehingga dalam dirinya terjadi perubahan dari tidak mengetahui menjadi mengetahui, dari tidak terampil menjadi terampil, demikian seterusnya, dimana perubahan tersebut menuju kualitas hidup yang lebih baik dari yang telah didapat sebelumnya.

Untuk mengoptimalkan perubahan dalam diri siswa, maka siswa dikondisikan sedemikian sehingga perubahan yang terjadi dalam diri siswa diperoleh melalui pengalamanya sendiri dalam interaksi dengan lingkungannya. Pembelajaran kooperatif adalah aktifitas belajar kelompok yang diatur sehingga ketergantungan pembelajaran pada struktur sosial dan pertukaran informasi antar anggota berlangsung tinggi dan tiap anggota bertanggung jawab untuk kelompoknya dan setiap anggota kelompok terdorong untuk meningkatkan pengetahuanya.

Dengan berpedoman pada teori tersebut belajar yang dialami siswa sangat bergantung dengan metode belajar yang digunakan, semakin baik metode yang digunakan akan semakin tinggi pula perubahan yang diperoleh siswa. Salah satu metode belajar yang dapat berperan optimal dalam meningkatkan penguasaan materi adalah menggunakan Think Pair Share (TPS). Yaitu pembelajaran kooperatif yang dikembangkan dengan mendorong siswa untuk menjadi reflektif terhadap materi pelajaran. Memungkinkan siswa untuk merumuskan secara pribadi pengalaman mereka dan berbagi pengalaman dengan anggota kelompok lain serta mendorong siswa untuk berpikir tingkat tinggi dan mengembangkan keterampilan dalam menyelesaikan masalah.

Dengan memahami keterkaitan kegiatan belajar dengan pencapaian hasil belajar jelas bahwa penggunaan Think Pair Share (TPS) mampu meningkatkan hasil belajar siswa, dibanding dengan siswa yang diberi pembelajaran tanpa menggunakan Think Pair Share (TPS). Dalam hal ini siswa yang diberi pembelajaran melalui Think Pair Share (TPS) memiliki rata-rata hasil belajar 85,26 , sedangkan nilai terendah adalah 73,00 dan nilai tertinggi 97,00. Nilai tersebut lebih tinggi dari pencapaian hasil belajar siswa yang diberi pembelajaran melalui Problem Based Instruction (PBI) dimana nilai rata-rata hasil belajar adalah 63,68 dan nilai terendah 57,00 serta nilai tertinggi 73,00.

Siswa yang diberi pembelajaran melalui Think Pair Share (TPS) memiliki nilai median 86,00 dan modus 97,00. Nilai tersebut lebih tinggi dari hasil belajar siswa yang diberi pembelajaran melalui Problem Based Instruction (PBI) dengan median 63,00 dan modus 57,00. Berpedoman pada kondisi tersebut dapat disimpulkan bahwa terdapat pengaruh model pembelajaran terhadap pencapaian hasil belajar.

\section{E. PENUTUP}

Terdapat pengaruh penggunaan model pembelajaran Think Pair Share (TPS) terhadap Hasil Belajar Ekonomi pada siswa kelas $\mathrm{X}$ di SMA Kutabumi I Tangerang, Jawa Barat. Perbedaan tersebut ditunjukan rata-rata hasil belajar siswa melalui Think Pair Share (TPS) adalah 85,26 nilai tersebut lebih tinggi dari ratarata hasil belajar siswa yang menggunakan Problem Based Instruction (PBI) yang memiliki nilai rata-rata 63,68 . Selanjutnya hasil belajar siswa menggunakan Think Pair Share (TPS) memiliki median 86,00 dan nilai modus adalah 97,00. nilai tersebut lebih besar dari hasil belajar siswa yang diberikan dengan menggunakan Problem Based Instruction (PBI) dengan median 63,00 dan modus besar 57,00 
Kesimpulan tersebut didukung oleh nilai terhitung dan nilai tabel . dari kondisi ini, usaha peningkatan hasil belajar Ekonomi siswa dapat dilakukan dengan menerapakan model pembelajaran Think Pair Share (TPS) dalam usaha meningkatkan hasil belajar didukung oleh karakteristik metode belajar tersebut dalam memberi kesempatan kepada peserta didik untuk aktif berinteraksi dengan/lingkungan belajar dan berbagi pendapat dan pengalaman dengan anggota kelompok.

\section{DAFTAR PUSTAKA}

Astuti, D. (2017). Model Pembelajaran Think Pair Share (TPS) Untuk Meningkatan Prestasi Belajar Mata Pelajaran IPS Kelas I. Jurnal Riset Dan Konseptual, 2(3), 328-334.

Kusuma, F. W., \& Aisyah, M. N. (2012). Implementasi Model Pembelajaran Kooperatif Tipe think pair share untuk meningkatkan aktivitas belajar akuntansi siswa kelas XI IPS 1 SMA Negeri 2 Wonosari tahun ajaran 2011/2012. Jurnal Pendidikan Akuntansi Indonesia, 10(2).

Mutatik, M. (2018). Upaya Meningkatkan Keterampilan Menulis Siswa melalui Penerapan Metode Think Pair Share. Jurnal Pendidikan: Riset Dan Konseptual, 2(2), 175-183.

Omeri, N. (2015). Pentingnya pendidikan karakter dalam dunia pendidikan. Manajer Pendidikan, 9(3).

Payadnya, I. P. A. A., \& Jayantika, I. G. A. N. T. (2018). Panduan penelitian eksperimen beserta analisis statistik dengan spss. Deepublish.

Suleman, S. (2018). Perbandingan Hasil Belajar Siswa dengan Model Pembelajaran Think-Phair-Share dan Model Pembelajaran Artikulasi terhadap Hasil Belajar Biologi
Siswa Kelas X SMA YAPIP Sungguminasa Kab. Gowa [PhD Thesis]. Universitas Islam Negeri Alauddin Makassar.

Surayya, L., Subagia, I. W., \& Tika, I. N. (2014). Pengaruh model pembelajaran think pair share terhadap hasil belajar IPA ditinjau dari keterampilan berpikir kritis siswa. Jurnal Pendidikan Dan Pembelajaran IPA Indonesia, 4(1).

Syafitri, W. (2014). Penerapan Model Pembelajaran Kooperatif Tipe Jigsaw Untuk Meningkatkan Hasil Dan Aktifitas Belajar Dasar-Dasar Gambar Teknik Kelas X Program Keahlian Konstruksi Batu Dan Beton Smk Negeri 1 Lembah Melintang, Kabupaten Pasaman Barat [PhD Thesis]. UNIMED.

Tanzimah, T. (2020). Keterkaitan Model Pembelajaran Think Pair Share (TPS) dengan Pendekatan Contextual Teaching and Learning (CTL) dalam Pembelajaran Matematika. Jurnal Dosen Universitas PGRI Palembang.

Trisnantoro, L. (2018). Memahami penggunaan ilmu ekonomi dalam manajemen rumah sakit. UGM press.

Winantara, I. D., \& Jayanta, I. N. L. (2017). Penerapan model pembelajaran TPS untuk meningkatkan hasil belajar IPA Siswa kelas V SD No 1 Mengwitani. Jurnal Ilmiah Sekolah Dasar, 1(1), 9-19. 
